\title{
Nuclear Medicine Contributes to the Identification of Brown Adipose Tissue in Adult Human
}

\section{Zheng Chen*}

Department of Molecular and Integrative Physiology, University of Michigan Medical School, Ann Arbor, MI 48109-0622, USA

\section{Introduction}

Brown Adipose Tissue (BAT) is present in rodents for whole life, and plays dominant effects on body weight, energy expenditure, lipid and glucose metabolism, providing a good target to cure obesity and diabetes [1]. However, in human, BAT was thought that it only exist in newborn or infant to maintain body temperature, and gradually gone in adults [1]. It is not clear whether BAT is present in adult humans and has physiological relevance because there was no good method to measure the mass or activity of BAT in adult human.

Recent studies in nuclear medicine suggested that the consecutive 18F-fluorodeoxyglucose can be taken up into adipose tissue, and the area with high 18F-FDG uptake putatively represented brown adipose tissue [2-4]. By using 18F-FDG positron-emission tomographic and computed tomographic (PET-CT) scans, three papers published on New England Journal of Medicine clearly showed that brown adipose tissue was present in adult humans [5-7]. Human BAT scattered at a region from the anterior neck to the thorax. Although the positive scan is only $7.5 \%$ in women and $3.1 \%$ in men under normal condition [5], 96\% subjects showed BAT activity during cold exposure [6]. Both immunostaining and gene expression date showed that UCP1, a BAT marker, was expressed in adult human BAT [5-7]. All these data demonstrated that brown adipose tissue was present in adult human.

Next question is whether identified BAT in adult human has physiological relevance. BAT mass and activity can also be measured by 18 F-FDG PET-CT scans. The activity was dramatically reduced in the overweight or obese subjects that in the lean subjects [6]. The BodyMass Index (BMI) and age had strong negative correlations with BAT mass and activity $[5,6]$.
Functional studies of BAT in adult humans indicated that BAT is a good target for the treatment of obesity and diabetes. More and more attention has been paid to the studies of BAT. It is one of the hottest fields in biomedical research. There were 3672 papers published in the last three years since BAT was identified in adult humans. All of these progresses are partly due to technical application of nuclear medicine. Nuclear medicine will continually contribute to the studies of brown adipose tissue in adult humans.

\section{References}

1. Cannon B, Nedergaard J (2004) Brown Adipose Tissue: Function and Physiological Significance. Physiol Rev 84: 277-359.

2. Cohade C, Mourtzikos KA, Wahl RL (2003) "USA-Fat": Prevalence is related to ambient outdoor temperature-Evaluation with 18F-FDG PET/CT. J Nucl Med 44: 1267-1270.

3. Yeung HW, Grewal RK, Gonen M, Schoder H, Larson SM (2003) Patterns of (18)F-FDG uptake in adipose tissue and muscle: A potential source of falsepositives for PET. J Nucl Med 44: 1789-1796.

4. Cohade C, Osman M, Pannu HK, Wahl RL (2003) Uptake in supraclavicular area fat ("USA-fat"): Description on 18F-FDG PET/CT. J Nucl Med 44: 170-176.

5. Cypess AM, Lehman S, Williams G, Tal I, Rodman D, et al. (2009) Identification and Importance of Brown Adipose Tissue in Adult Humans. N Engl J Med 360: 1509-1517.

6. Van Marken Lichtenbelt WD, Vanhommerig JW, Smulders NM, Drossaerts JM Kemerink GJ, et al. (2009) Cold-Activated Brown Adipose Tissue in Healthy Men. N Engl J Med 360: 1500-1508.

7. Virtanen KA, Lidell ME, Orava J, Heglind M, Westergren R, et al. (2009) Functional Brown Adipose Tissue in Healthy Adults. N Engl J Med 360: 15181525.
*Corresponding author: Zheng chen, Department of Molecular and Integrative Physiology University of Michigan Medical School Ann Arbor, MI 48109-0622. USA, E-mail: zhengch@umich.edu or chenzheng108@gmail.com

Received November 20, 2012; Accepted November 23, 2012; Published November 28, 2012

Citation: Chen Z (2012) Nuclear Medicine Contributes to the Identification of Brown Adipose Tissue in Adult Human. J Nucl Med Radiat Ther 3:e105. doi:10.4172/2155-9619.1000e105

Copyright: @ 2012 Chen Z. This is an open-access article distributed under the terms of the Creative Commons Attribution License, which permits unrestricted use, distribution, and reproduction in any medium, provided the original author and source are credited. 